\title{
Creating Commons: Reflections on Creating Natural Resource Management Regimes in South Sulawesi, Indonesia
}

\author{
Karno B. Batiran ${ }^{1,2,3^{*}}$, Nurhady Sirimorok ${ }^{1,2,3}$, Bart Verheijen ${ }^{3,5}$, Micah R. Fisher ${ }^{3,4}$, Muhammad \\ Alif K. Sahide ${ }^{3}$ \\ 1 PAYOPAYO Peasant School Network, Indonesia \\ 2 Doctoral Candidate of Forestry Science, Forestry Faculty of Universitas Hasanuddin, Indonesia \\ 3 Forest and Society Research Group (FSRG), Forestry Faculty of Universitas Hasanuddin, Indonesia \\ 4 East-West Center, United States \\ 5 Leiden University, Netherland \\ * Correspondence author: batirankb20m@student.unhas.ac.id
}

\begin{abstract}
Thirteen years ago, PAYOPAYO Peasant School Network, an Indonesian community organizing network based in Sulawesi, facilitated Participatory Action Research (PAR) that eventually culminated in a creation of a common resource management regime around an irrigation system for agricultural use in Tompobulu, a village within a national park in upland South Sulawesi. This note from the field presents a reflection on collective action experiences of a community in building the commons in 2008 to 2009, and revisits the extent to which the commons has been managed, how management regimes changed over time, and how it survives as a commons today. The initial factors allowing for establishment of the commons, understood here as a social practice toward common goals, were a shared need for water (local needs \& conditions), and the success to make use of the irrigation commons as a means to initiate other collective actions. Drawing from concerted engagement and analysis conducted in 2021, this note revisits the key factors and highlights different ways the commons continues to persist, namely due to the distinct benefits felt by participants, the existence of institutions that regulate the use and maintenance of the commons, the existence of a monitoring system among members, participation of members in formulating and modifying the rules, and the recognition of National Park authorities on the commons and its rules.
\end{abstract}

Keywords: Commons; Commoning; National Park; Collective action; South Sulawesi; Indonesia

\section{Prologue}

Once upon a time, according to the belief of the Tompubulu community, there was a large rock rolling from the top of Mount Saraung to the river that runs at its feet. The river where the rock stopped was named the Batummoppo River. It is a small river that originates and flows from the forest of Mount Saraung in the Bantimurung-Bulusaraung National Park area (see Figure 1). In the Dentong Language - the language spoken by the people of Tompobulu, a variant of the Makassar language-'Batummoppo' means 'batu' (stone) and 'moppo' (rolling down and then sitting still), combining to mean a stone that falls and then sits still.
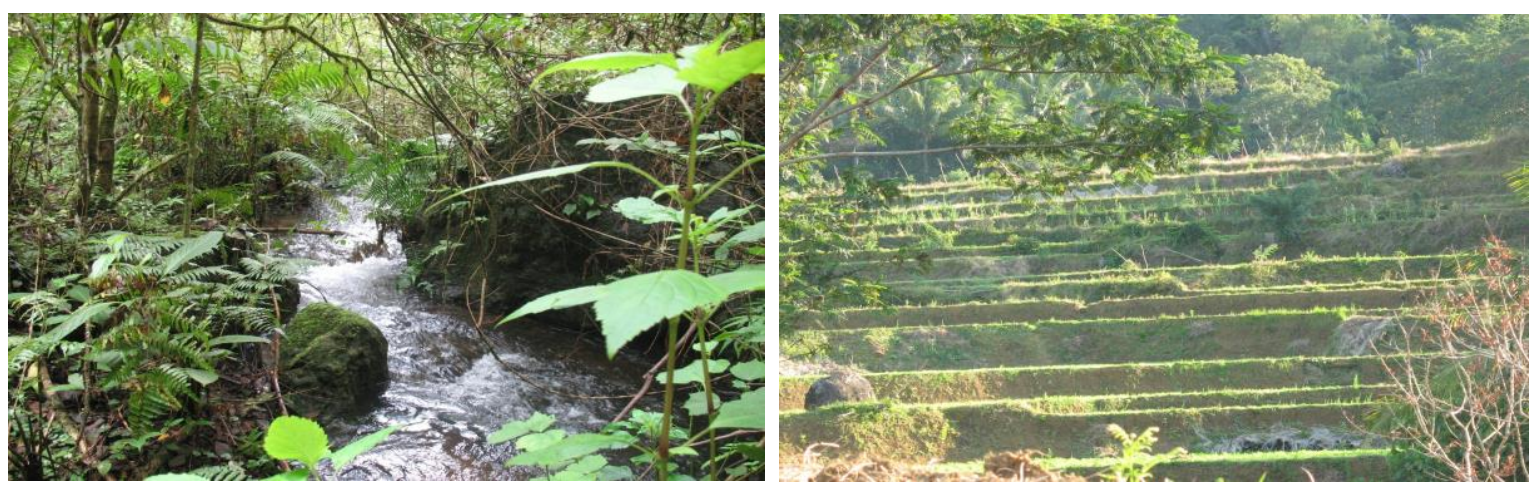

Figure 1. Tompobulu village is located within the Bantimurung-Bulusaraung National Park area. 


\section{Revisiting Tompobulu}

In mid-June 2021, I (first author) visited Tompobulu, which is administratively located in the Regency (Kabupaten) of Pangkep, South Sulawesi. I started to work in Tompobulu in October 2007. I was keen to learn more about community organizing in the rural setting. I wanted to be a rural organizer, and my organization ${ }^{1}$ was starting to be seriously working in villages, and we need a kind of social laboratory in a village and a member to run it. But this time I exclusively came to better understand the irrigation system that local farmers built at that time. This small scale water management system was initially established to increase irrigation capacity to increase the production of rice and groundnuts in the dry seasons, and was established in a way that reflected the main attributes of a common property resource regime (Ostrom 1990; Euler, 2018; Vaccaro and Beltran, 2019), because it was a socially constructed resource management system that is collectively controlled and managed by a group of people. I returned in mid-2021 to better understand whether and to what extent the system was still used and managed collectively. My visit also provided an opportunity to more broadly reflect on the processes that created and maintained collective action around their commons. Therefore, I will explain the phases that lead to the construction of not only a physical system around a resource but also the institutional arrangements governing the system. In other words, this writing will narrate a process of commoning, a social practice that is voluntary and inclusive, taken up by a group of people to satisfy their need, and in doing so the create and maintain commons (Euler, 2018)
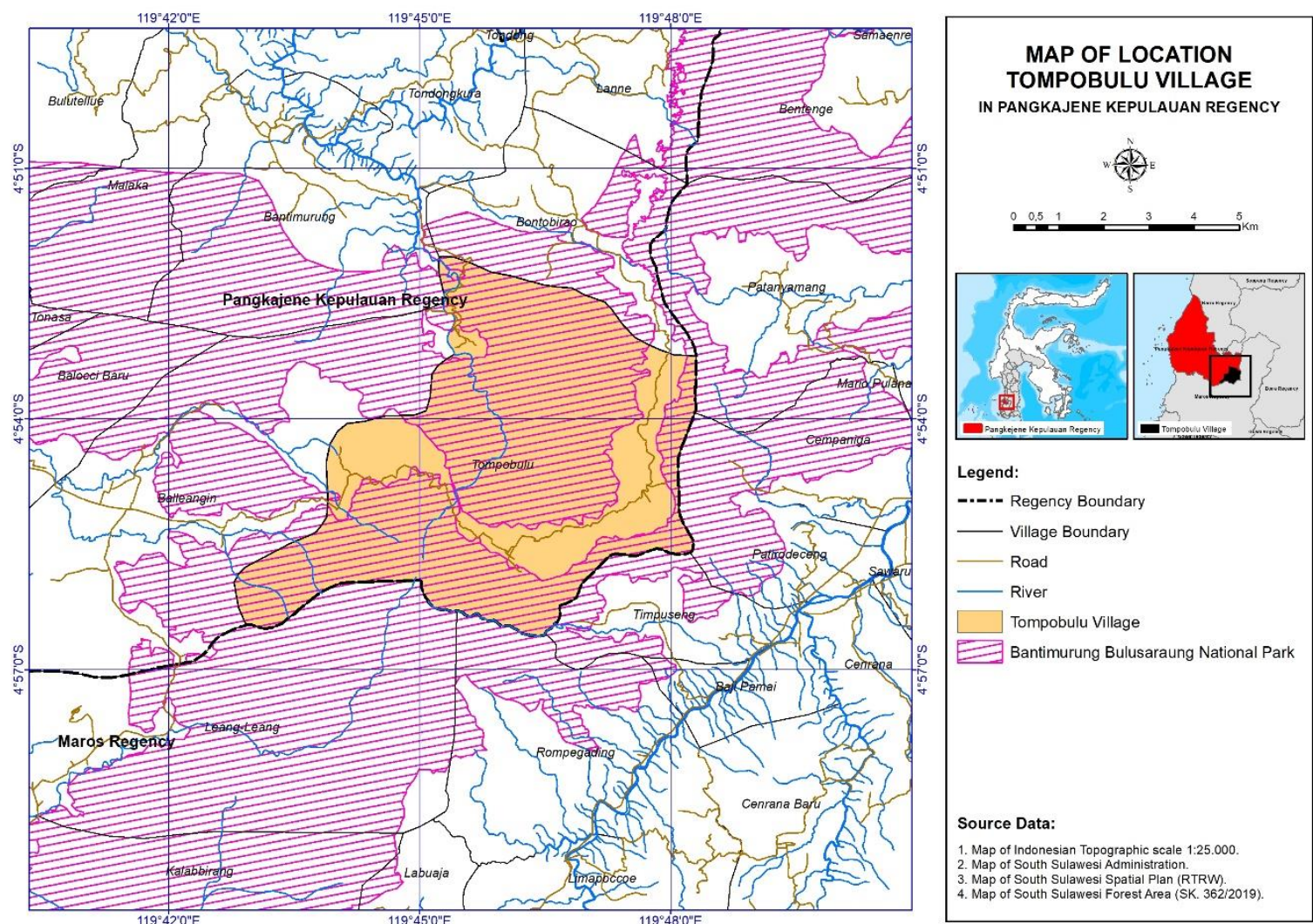

Figure 2. Map of Location of Tompobulu Village

The first time I visited the village of Tompobulu (see Figure 2), I came with several friends to look for a site for a fieldwork training program for a group of graduate students. We drove through a poorly maintained concrete road from Balocci, a district town, until we hit the end of the road. Tompobulu is the farthest village of the district. The village was and is still a remote village at the foot of Mount Bulusaraung.

Stretching from the west to east foothills of Mount Bulusaraung, at approximately $700-800$ meters above sea level, the temperatures in Tompobulu is averaging around 18-22 degree Celsius,

\footnotetext{
${ }^{1}$ The organization here is Ininnawa, a federation or CSO where Payo-Payo is a member organization.
} 
cooler than the surrounding lowland coastal areas. To get to the village, one must first drive north from Makassar, the capital city of South Sulawesi Province, for about 50 kilometers, passing the remains of Semen Tonasa I along the way, which is an abandoned cement factory and mining town. Tompobulu village is one of the stop points for hikers that intend to visit the peak of Mount Bulusaraung, which is located within the jurisdictional boundaries of the Bantimurung-Bulusaraung National Park.

Although connected by concrete road from the sub-district town since 2002, it is not easy to reach Tompobulu. The road has several combinations of steep and sharp turns. Cars and motorcycles have to be in the lowest gear to be able to manage the climb. A switch to gear two during the climb can cause the vehicle to back down and may fall into ravines that appear along the roadside! During the rainy seasons, moss covers the concrete road making it especially slippery and dangerous. First time drivers or riders need extra caution to navigate the road. The mere $35 \mathrm{~km}$ distance between the nearest town and Tompobulu requires more than an hour drive.

Upon entering the village boundaries, a series of green painted signs are posted at the roadside, each carrying phrases painted in white Arabic script, with Indonesian translations underneath. The posts are Islamic praises to God such as, 'Subhanallah' (God is perfect), 'Alhamdulillah' (All praise and gratitude belongs to God), 'Allahuakbar' (God is the greatest) and correspond to certain landscape features. For instance, at the side of a steep climb the post reads 'Subhanallah', a phrase that local Muslims customarily utter upon facing adversity. At a level road after a difficult climb, the post reads 'Alhamdulillah', a phrase people say in gratitude to God. And at the spot one can enjoy the beautiful and expansive scenery, the sign reads 'Allahuakbar', to acknowledge God's greatness. The village is a pilot site for Syariah (Islamic Law) enforcement in the district. The Syariah is written in the Village Regulations, one of which is that all women should cover their heads when going outside of their houses.

On this latest visit to Tompobulu, I arrived at Mr. Najamuddin's house, an individual I visited regularly and who had become one of the farmer leaders since the work began on the irrigation project. Other farmers also saw a visitor and also customarily stopped by to chat and catch up. I explained my interest in better understanding about the longstanding irrigation initiatives, and the extent to which it continued to support the essential infrastructure for village livelihoods. From this visit I learned that there are at least four aspects that prove that the irrigation system can be seen as continuing the commons after 13 years. First, irrigation is still providing a similar benefit after all these years. Second, the rules the farmer drafted and approved remain intact. Third, they succeed in maintaining a mechanism for conflict resolution among the members. Fourth, higher authorities such as the village government and National Park acknowledge and respect the water user group as well as the rules they have devised.

\section{Tompobulu: the village inside the National Park}

The forest, land, and water are the most important resources for Tompobulu as agriculture is their main livelihood. The village is surrounded by dense forest vegetation and karst mountain areas that store an abundance of water. Nevertheless, most of the paddy fields in Tompobulu can only be planted once a year due to the lack of water. Several grasslands are also used for grazing areas, which provide enough fodder for their cows. The series of karst mountains, which serve as giant water towers, loom over the village, creating an ecosystem with unique and heterogeneous vegetation as well as providing water supply all through the year. Located within the National Park, the ecosystem is also well preserved, reducing the number of pressures on the landscape. However, since operations of the Bulusaraung-Bantimurung National Park were formally established in 2004, and its boundaries finalized in 2006, the village of Tompobulu has experienced changes in the way villagers can access and manage resources.

For instance, Tompobulu used to have a reputation as a brown sugar producing community throughout the regency. In the past there were 10 groups of brown sugar producers, each producing 100 cubes of brown sugar a day. Since the National Park establishment enclosed access to sugar palms, however, the stands of sugar palms have drastically reduced, causing village brown sugar production to dwindle up to $90 \%$, amounting to a mere $4-5$ cubes a day in the 2000 s, after the park establishment. An important livelihood and income generating source was curtailed. In addition, 
women and children used to be able to roam the forest to collect candlenuts for additional income but those have also become off limits since Park establishment.

Water sources among these karst landscapes are abundant. However, villagers experience difficulty in accessing them, especially for the critical role of rice and seasonal secondary crops production. Rice fields, which produce peanuts in dry seasons and provide a key cash source in Tompobulu, are mostly managed through rainfed systems. During the dry seasons, June to October, the farmers planted peanuts on the rice fields and hoped that enough rain would come down to water their crops, aside from a handful of farmers who were watering their plots, drawing from springs and small streams with much receded volume during the dry season. They did so in an inefficient manner. Individual farmers whose rice field plots are far away from the water sources use small plastic hoses over great lengths - hundreds of meters - to deliver water to their individual plots. Each farmer is responsible for their own small plastic hoses, and farmers who could not afford them must make do with only the rain water. In short, the initial problem that we were identifying in 2007 was the absence of a collectively managed irrigation system that could more easily facilitate water access for parts cultivated lands.

This water problem becomes even more critical if we examine the overall village agricultural and land use system. Rice and peanuts are their main crops. As subsistence cultivators, the farmers plant rice mainly for their own consumption, and only a fraction of the surplus is sold only when they are certain that the next harvest would be successful. Peanuts are planted mainly for selling to fulfil various financial needs such as education (school fees and daily spending for children who go to middle-schools and colleges in nearby towns) and health services (pay for medical services in hospital, as many villagers were not registered in the medical insurance programs that cover hospital services). During the rainy season, between November and April, cultivators have enough water for the rice planting season. In the dry season however, between June and October, they only receive occasional rains. It is during the dry seasons that peanuts are planted because some of the farmers can only water their plots with occasional rain and have experienced decreased water volume from some small streams and springs-provided that their plots are close enough to the water sources for affordable small plastic hoses.

Because of the unique land use in Tompobulu, increasing income through rice is impractical. The available rice fields are limited and extensification is impossible since a good portion of the village is designated as part of Bantimurung-Bulusaraung National Park. Bulu-Bulu, the largest hamlet in the village, only has around 50 ha of rice field. Out of the 442 households in Tompobulu, 118 live in the hamlet of Bulu-Bulu and all work as farmers. Tracts of flat lands for rice fields are spread among the ravines and hills. These lands have specific names due to their importance, and two of the largest plots are named Lompo Lebang and Acce. There are 47 households, a total of 114 people, who have access to the rice fields and depend their livelihood on these two tracts that cover around 15 ha. These lands experience annual droughts rendering cultivation difficult. The collective action to build irrigation took place to water these two tracts of land. There are three springs used for rice fields in Acce and Lompo Lebang, which experienced decreased water volume during the dry seasons and thus could only be used by a few farmers. Based on the farmers' daily observations, they know that the problem was not the water availability, but that leakages along the distribution lines did not convey the supply they required. To solve this problem, several farmers have thought about ways to transport the water from other sources and began to consider approaches to managing it collectively. They knew that there was another larger water source from near the Batumoppo river. The problem was that the spring was located far in the forest, at the upper part of the hill, around 3 kilometers from the rice fields. Additionally, although Batumoppo river is administratively located within the Tompobulu village, the site is located within the National Park boundaries. The river was not used for agriculture nor for household needs, because the direction of the river flows south, away from the village. By redirecting some of the water, the farmers were certain that its volume could help overcome the water scarcity challenges they were facing in Lompo Lebang and Acce during the dry season. They only needed to transport and use the water efficiently.

The farmers predicted that if they could transport the water to the rice field in Lompo Lebang and Acce, the peanuts yields would also increase by up to 30 to $50 \%$. So, if the farmers normally harvested 60-70 litres from 10 litres of seed planted, with scheduled watering they predicted gains 
of 100-150 litters out of 10 litres of seed. This calculation was based on the farmers' experience in 1997, when the rainy season came later than usual just in time when they planted the peanuts. As a result, the peanuts received adequate water, and provided the basis for their estimate of higher yields.

Previously, some of the farmers tried to build a simple irrigation system by digging a gutter from a small dam built in the upper part of the river. But the water volume decreased significantly during the dry season. The water flows receded quickly along the way, seeping into the ground before reaching the rice fields. The farmers knew that transporting water to the rice fields needed pvc piping to a reservoir site that could be built within the rice fields. With this proposed solution another challenge emerged: how to acquire expensive pvc piping to build the new irrigation system, because at that time the price was unaffordable.

\section{Collective action in building irrigation}

On an afternoon on my latest visit to Tompobulu, I met and talked to Hairi and Manci. They are now in their forties but were young farmers who took part in the initial phase of the irrigation project. They were among the pioneers before more farmers got involved. Opening our conversation on this visit, I asked them whether the irrigation system is still physically operational in the initial form of the small dams, pipes, and reservoirs. They replied eagerly, explaining that it still exists and continues to work as intended:

"To me, irrigation will most likely still exist for generations to come," Hairi added. "We still enjoy the benefits, and without the water we would not be able to plant nuts in Acce and Lompo Lebang." They also confirmed that the sources still provide adequate water "just like in the past."

This simple answer in fact represents a remarkable achievement, and reflects a protracted process whereby a handful of farmers began to self-organize, convene new participants, build and maintain the irrigation system and its institutional arrangements, as well as cultivating collective action long after the original initiative to build their own commons.

When I started the organizing work toward the end of 2007, it began with hanging out with the village male youths who I knew from previous programs. ${ }^{2}$ From there I got closer to two male young farmers who were willing to do something about their village: Manci and Hairi. With this small team of three, we first learned to do a simple assessment, identifying what the village has and issues they currently face. It was from this activity that I heard the issue of water shortage in the village's two main tracts of rice fields, that they did not receive enough water at the desired schedule. The discussions then began to roll with the two young farmers and the commitment strengthened to realize activities to tackle the problem. Using the momentum, I introduced the concept of community organizing that we can apply to what they describe as "to make the village better". In other words, we did an envisioning on how to materialize their aspiration to provide sufficient water to the rice fields. In this process I support them with stories about organizing activities from different places, while also elicited organizing examples that have been done in Tompobulu. For instance, there were successful organizing activities in one of the village hamlets for coffee planting and a small and basic irrigation system. The stories become precedents that the Tompobulu farmers were in fact able to organize themselves, although they are short term and smaller in scale. Once the image of organizing activities becomes clearer in the young farmers' heads, we then identify other people who would be willing to join, especially those who can attract more farmers, and those who cultivate rice in the two tracts of land. As they did this, my understanding was growing that villages did want to solve the water problem but they just did not believe they could.

Since mid-2008, serious discussions ensue among several pioneer farmers and I (the first author). We discussed what farmers should do to tackle the water problem. We decided that this problem needed an organizing activity. We were certain that successfully transferring water from Batumoppo to the rice fields in time for the groundnut planting season would bring about significant

\footnotetext{
${ }^{2}$ Ininnawa members have used Tompobulu as a host village for two previous activities before I came to organize these activities. First, a two weeks fieldwork training program that brings graduate students from Japanese universities, organized by Foundation for Advanced Studies on International Development (FASID), Tokyo. Second, a women novel writing training that brings aspiring women writers to study rural issues to support their creative writing processes.
} 
sustainable benefits. Aside from resolving the water issue, an organization would initiate the farmers to think seriously to take their issues into their own hands. We increasingly believe that it would be able to stimulate other farmers to realize that they could take part in important public issues, exerting their own agency to determine their own aspirations. And later they would realize that it would be easier to organize farmers after they saw the real benefits of collective action. Overall, irrigation was an urgent need for the farmers, which was a problem that they alone identified and solved.

With this collective action, we expected to be able to build the villagers' confidence that they can actually do something with their own resources. We also believed that the plan would be able to rebuild trust among the farmers and villagers as a whole. The low trust among the farmers can be seen from their comments, such as the following cynical comments: "If only the water can be transported to the rice fields, it won't be you who would do it and not now, I should've been able to do it before you!" Indeed, there was an attempt to channel the water from Batumoppo, but it was only done by a family, so other farmers saw it as a close relative affair. This sentiment has a history.

For decades, since the New Order era, the villagers have been too familiar with the top-down management of the government infrastructure projects. From the villagers perspective, this practice has become a rule, where the state projects are controlled by the village elite circle who also dominated the public decision making, and the ordinary villagers-a handful of them--merely participated as wage workers to implement the projects. Therefore, it was widely believed by the whole village that any infrastructure project with a substantial scale like the irrigation system they planned to build can only be realized with funds from the outside, managed by the village elites, with the rest of the village either watching or involved as the wage workers (Sirimorok and Hawi, 2014). After the New Order, a decision-making system for village development program through supposedly bottom-up village deliberation (musyawarah desa) faced multiple challenges such as, elite domination in formal village meetings and selection-based budgeting for village program funds. Fierce competition among villages ensued to get their programs into selected programs decided in the district level development planning meetings (musyawarah rencana pembangunan kecamatan), which once again to be competed against other districts programs in the development planning meeting in the regency level (musyawarah rencana pembangunan tingkat kabupaten). This system led to the fall of many important village programs along the budgeting processes. As a result, the ordinary villagers are still dependent on their elites to turn their aspirations into formal village budgeted programs. ${ }^{3}$ This longstanding top-down practice created dependency on outside projects, including the funds involved in them, and low trust among the villagers as to their own ability to initiate, plan, and implement their own projects. In addition, inviting villagers for substantial collective work like building irrigation systems without a wage would likely raise a public suspicion that the fund is supposedly available and was not distributed. In the context of the farmers irrigation project, a kind of silent suspicion was prevailing among the villagers when a small group of ordinary farmers decided to initiate something for collective benefits.

With these understandings the small group of ordinary farmers were determined to realize the villagers own project, and decided to involve more farmers since the initial phase. We also involved several older farmers to encourage participation of all farmers that cultivate rice fields in Lompo Lembang and Acce'. We also considered that the project will eventually face the National Park, it would need some older farmers to negotiate with both other farmers and the National Park. The strategy worked. They lobbied with the village government and National Park.

We then began to informally discuss and disseminate the irrigation idea to all the farmers who cultivated rice in Lompo Lebang and Acce'. The process of inviting the farmers was conducted in rice fields, gathering occasions, and even at their houses, especially for those who are pessimistic about the idea. The community action on building irrigation can be seen in Figure 3 .

\footnotetext{
${ }^{3}$ The system practically ended around 2015 when the Law No. 6/2014 on village governance began to be implemented.
} 

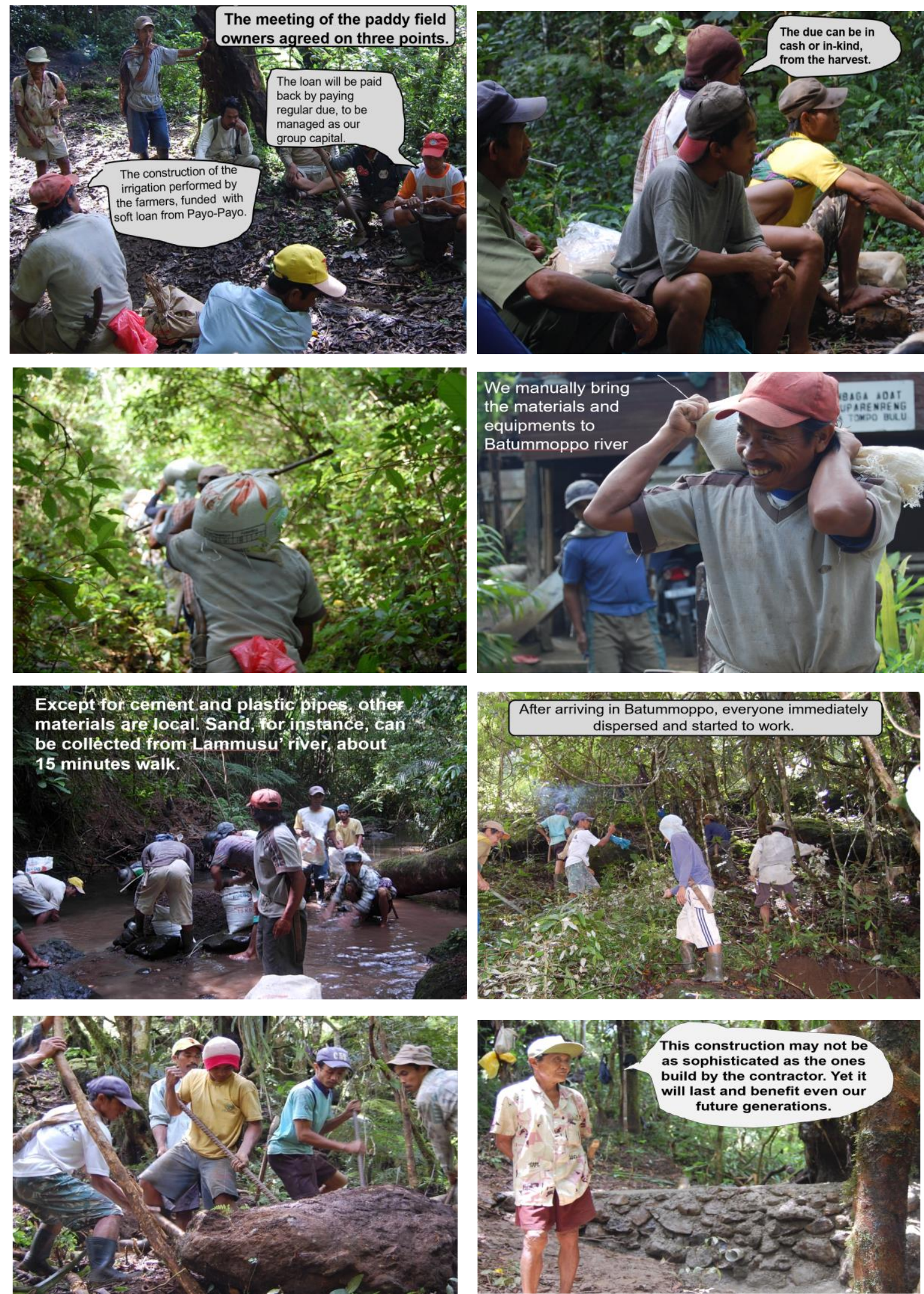

Figure 3. The 'collective action': working on building dam irrigation

Through a series of discussions with more farmers, it was concluded that this project is feasible and will be materialized. Previous to discussing the overall financing, the farmers convened to discuss the technical specification of the initiative. They came up with the idea that in order Tto channel the water from the upstream of Batumoppo to the rice fields in Lompo Lebang and Acce', a 
small dam would be built to contain the river flow. The dam measures around 12 meters wide, 1 meter high, and the wall is 1.5 meters thick. The contained water will be channeled using a larger ( 2.5 inch diameter) pvc pipe, totalling $3 \mathrm{~km}$ in distance, which runs through the forest and goes down from the mountains to the rice fields. At the end of the pipe, the water is contained again in two small concrete reservoirs, one at each corresponding site: Lompo Lebang and Acce. The concrete building is 5 meters long and wide, and 2 meters high.

From the reservoirs the water would be carried by the piping system to the rice fields with rules the farmers agreed to. It was predicted that the construction of the dam, piping system, and reservoirs would take 15 to 20 work days to complete, provided that a minimum of 10 people would volunteer their time. They also agreed that all of the work must be done by the farmers themselves.

But an important issue remained: after calculating the costs, the villagers found that the project would require Rp. 60 million (or USD 6,500 based on 2008 exchange rates). This became the biggest question of the project: where would the money come from? Collecting it from the farmers at that point was impossible as they were too dependent on outside projects and too doubtful and unfamiliar with their own ability to procure and manage a collective facility. Indeed, all farmers shook their heads rejecting the idea. In order to provoke a new way of thinking about funding a project, I asked whether it is possible to collect that kind of money among them. I explained that in context, Rp. 60 million was relatively small compared to the many government projects that came to the village, including those that did not end well and were unsustained that reached amounts of hundreds of millions.

In discussions with the farmers, many ideas began to emerge about how to collect the money. Getting funds from formal credit programs was dismissed because the farmers worried about being unable to repay the credit, and the procedures were too complicated for them. The most expensive cost would be to procure 3,000 meters of 2.5 inch pvc pipes. There was an idea to replace them with bamboo, but this was rejected due to durability and maintenance concerns.

And the idea of making a proposal to be handed to local government or donor agencies was also rejected as they thought the process would be too complicated and would take too long to complete.

When all these financing ideas were exhausted, the villagers were on the verge of despair over the construction plan. I suggested the idea of finding a soft loan (without interest and with longer or no time limit for the repayment). This idea was agreed upon and I placed myself in the position of collecting the funds, even though I was still unclear on how I might raise the entirety of the funds. The most feasible possibility at that time was to run a fundraising campaign with some friends and networks of NGOs who might find enough people willing to help bring about this idea, or collecting loans from several friends until they reach the required cost. The idea was well received by the farmers.

In turn, I said that I will only work on it if the following conditions are agreed. First, all construction processes must be done only by the farmers. This included an assessment to determine the dam and reservoirs locations, measuring and designing specifications, accounting details, and transporting the required material, providing food and refreshments during the construction, coordinating the meetings, constructing the facilities, and providing construction materials that are available within the village such as rocks and sand. This way we only had to buy those materials that are unavailable locally, like pipes and cement. Second, the farmers must commit to maintaining the irrigation system in the longer term, which would be accompanied by rules that they would draft and agree collectively. Third, it is not a 'project' in the sense of the government or NGOs' projects where those involved often get financial compensation or individual benefit. Fourth, the project is funded by a loan, and therefore has to be completely repaid.

Once these terms were agreed I began to organize to collect the funds for the loan. Meanwhile, the farmers began to refine the plans. They reassessed the plans in more detail: reevaluated the length of the pipes needed, found and determined the dam and reservoir locations, identified materials available in the village, and adjusted costs based on the reassessment. This adjustment also helped reduce the costs, and with savings on labor and materials, they determined they only needed Rp. 40 million (USD 4,200).

Six months passed and there was no sign of a loan opportunity, and to maintain the spirit and 
commitment, we told the farmers that the fundraising was still continuing and several people had shown interest. At the end of 2008, some NGO friends visited us in Makassar, accompanied by two members of the Student Board of Helsinki University, Finland. They came to seek the possibility to run a program on the issues of sustainable food and energy in rural areas. We drove to Tompobulu, stayed for a couple of days while walking around and talking to the farmers. During this trip they heard the story about the independent irrigation project. They were interested without showing any explicit promise to support. But at the end of the year called to inform me that the Student Board of Helsinki University was willing to share some of their cafe profit for the irrigation project.

They only required us to draft a simple proposal that contains the important details about the irrigation plan, such as the costs, number of beneficiaries, management model, etc. (see Figure 4 for the map on water channel plan). Although this proposal was written for a grant, our internal agreement with the farmers still remained. The grant, as soon as it reached the farmer group, was to be seen as a collective loan and should be repaid in full. This was only possible because the student organization did not require complicated financial reporting.

Forty million rupiahs was transferred and the farmers project began on February $13^{\text {th }}, 2009$, at $2 \mathrm{pm}$, after the Friday muslim prayer, whereby a meeting was convened at a house of one of the farmers. It was attended by 29 people, 4 from Payo-Payo (including me), and the rest were farmers. Out of 43 families in the beneficiary group, only 25 attended. They talk about the details of the construction such as the number of pipes and cement needed, and when to start.
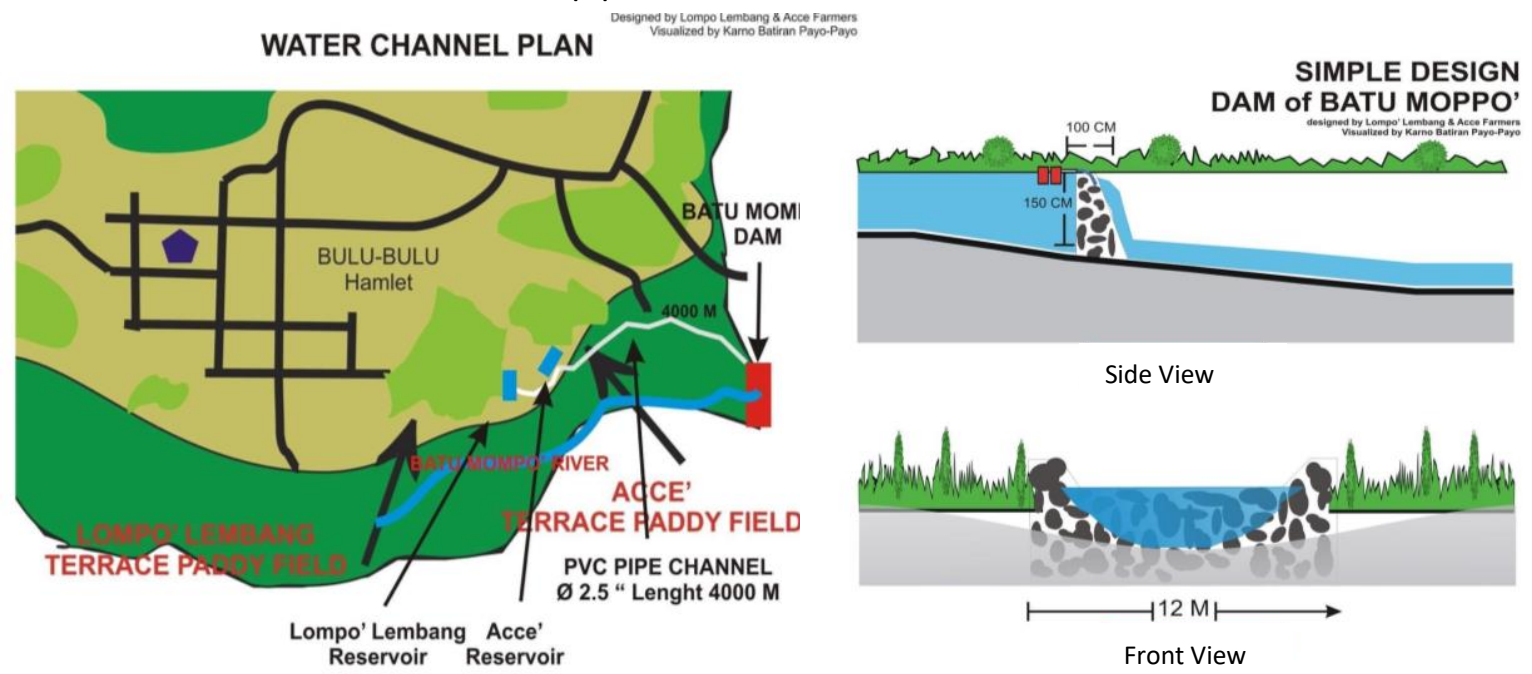

Figure 4. The map of water channel plan and the simple design of Batu Moppo' DAM

Although they plan to only talk about the practical details, they decided to also talk about the repayment and monthly contribution to maintain the irrigation system. It was also agreed to have regular meetings in between the construction work. After finishing the construction, they also agreed to convene another meeting to finalize all the details agreed upon in the regular meetings, including management of water use, and the formation of a water user group.

Early in the meeting a farmer proposed to strengthen the commitment on the financial contribution and maintenance. I offered that it would be easier to pay for the contribution in kind after harvests, such as through peanuts or corn, or any other crop they planted in between the rice seasons. I also suggested that before the construction begins, several farmer representatives need to ask permission to build the small dam in the National park area. They agreed, went to visit the National Park office, and got the permission.

On Wednesday, March $5^{\text {th }}, 2009$, the first construction work began. It would take 27 straight Wednesdays of construction before the water was successfully carried to the rice fields. The work then continued to November 2009 for finishing such as burying the pipe to avoid exposure to the sun and animals trampling the system, and roads were improved for easier access to the rice fields. After 40 Wednesdays from March to November, the irrigation project was completed. 


\section{Maintaining collective action}

"Why do you think the irrigation remains intact and is working?" I asked Hairi and Manci. "Why, because it is maintained well, each season it's pipes are checked and replaced if need be," said Manci.

Supri, who is entrusted with collecting regular contributions and serves as the book keeper of the group, confirmed that the irrigation maintenance is regularly done each planting season and each time damages are identified, especially if it involves the piping system. The maintenance costs are reserved from the individual contributions of the members. Although a few members sometimes miss the schedule, the total amount is always enough to cover maintenance.

It is interesting to notice the changes in Hairi, Manci, and Supri, who are now in their forties and how they speak about something they helped to build in their twenties. It shows how a common resource pool can become a sustainable commons when a group of people decide to manage them collectively. It shows how they, young ordinary farmers, began by doing a simple assessment that teases out the important shared issue of water shortage, continued with visioning concerning selforganizing processes. With clearer vision, the commoning proceeded with the dissemination of the idea to other villagers, where they struggled to build trust on the farmers own collective bottom-up initiative. Substantial participation of the larger number of farmers from this outset facilitated their shared understanding of the whole processes and objectives, built long standing commitment, and played some role in attracting yet more farmers to get involved. Their confidence also reflects how they succeed in bringing about and self-navigating the physical collective work to construction of the irrigation system, and later in the rule making processes that stem from a real need to manage their newly built collectively owned infrastructure.

In Tompobulu, agreements in maintaining the irrigation system really began to take shape on the 29th Wednesday into their construction work, when the farmers drafted the terms of agreement on rules around water use. They formulated the details on rules for repayment and maintenance contributions, which have continued to remain in place for 13 years. Also, I decided that this event would be a good time to reveal where the financing had come from. When I secured the funds I did not mention that the money they used for the construction was in fact a grant from students of Helsinki University. Until then I was not sure about their commitment to long-term maintenance of the irrigation, and the grant management allowed me a degree of management liberty. In the meeting where we agreed on the irrigation management rules, I disclosed the information to the farmers. Their response showed that their commitment to collective action has slowly but steadily been getting stronger: they decided to keep their previous agreement to provide individual financial contributions. Instead of choosing to consider the money as something that is totally expendable, the farmers agreed to treat the grant as their collective savings that needed to be repaid after spending most of using it for the construction. The grant then became the savings for the user group that they established. The repayment was due after each harvest, in cash or in-kind (nuts, rice, or other crops planted), and managed by the newly established user group. The amount and duration of the repayment was approved by the members and management of the group, considering the size of each of the users.

With these agreements they established a Water Group for the farmers of Lompo Lebang and Acce. The group then became a precedent cradle for subsequent collective actions that currently work for self-organizing activities in Tompobulu. They have been working on it through agricultural experiments, introducing organic agriculture, collective learning, building biogas installation for alternative energy, and others.

These rules, in their current form, also proved to be significant in avoiding conflict among users. On my last visit, I jokingly asked Manci, "Has there been any conflicts? Because such a valuable resource like water can usually spark conflicts."

He admitted that, "Yes, sometimes these things happen." To gain further insight into these conflicts I sought out Najamuddin, who is usually entrusted to handle sensitive issues like conflicts around water. He is difficult to find however, especially since his appointment as head of Bulu-Bulu hamlet. I and others believe that this appointment partly resulted from his active involvement in village public affairs that began during the irrigation project in 2008-2009, and his accountable way 
of addressing issues indicated his commitment to accountability. As I sat with him in the late afternoon, I asked about the causes of conflicts around the irrigation system, and what people had been doing to resolve them. Najamuddin explained that individual farmers who water their own plot excessively is the main cause of the conflict. These individuals violate agreed upon scheduled watering that determines their allocation and access. This inevitably creates bitterness among the users that are denied access. To resolve this problem Najamuddin and other older farmers would visit violators and explain the importance of maintaining the schedule and how improper usage disrupts the entirety of the distribution system, also explaining how important it is to avoid conflict. Such explanations generally worked.

Aside from the economical advantage to the farmers of Lompo Lebang and Acce, other benefits that had been predicted in the earlier phase of the project gradually were realized, such as the rise of a number of farmers continuing to self-organize. This project, to some extent, created momentum for the farmers of Tompobulu to organize themselves, reclaim roles that were previously out of their hands. One important role that began to develop was the involvement of the water group in the village development planning process. Although an annual Development Planning Deliberation (Musyawarah Perencanaan Pembangunan, Musrenbang) is scheduled for villager involvement, these formal events were not effective in incorporating local aspirations. As is common elsewhere in Indonesia, a few outspoken locals dominate these formal meetings, those who have more power and have the ability to speak fluently in public meetings - and therefore tend to exclude others who are unfamiliar with formal forums and articulating their concerns and interests.

The farmers self-organizing also materialized in the water user groups. It is a group that grew out of their actual needs and also supports them in speaking out collectively. A number of similar groups had been established in the village before them, ranging from farmer groups, youth groups, to women groups. However, most of them were established to serve needs from outside the village. For example, government rural aid programs usually require the formation of segmented groups in order to distribute various aid. Indeed, these kinds of groups sometimes only exist on paper to facilitate top-down implementation of government programs (Sirimorok and Hawi, 2014; Prabowo et al., 2011). This practice is widespread in the province of South Sulawesi.

Meanwhile, predictions that the irrigation project would rebuild farmer collective selfconfidence were also clear. Having participated in the water user group, they have over time built a road to the rice fields and farmers covered the entirety of the costs. The road, three meters wide and 300 meter long, was successfully improved collectively with their own leadership and initiative. The road would have required more than $\mathrm{Rp} .100$ millions without their participation - and had they decided to wait for some outside support it would most likely have taken too long before it materialized.

On an evening in mid-November 2009, a celebration was held in the village mosque, in BuluBulu. There was singing and sounds of music from traditional wooden mortar and Islamic-derived acoustic instruments (gambus). A group of older men were chanting the life story of Mohammed in Arabic, ma'barasanji and other traditional art performances ensued. They call this event the 'Ceremonial feast for harvest and gratitude for Batumoppo water.' People from seven hamlets gathered and enjoyed the performances.

Just a few hours before, dozens of farmers were gathered and rallied in front of the village head house, who had refused their request to use the mosque yard for the celebration. Instead, the village head offersed the much smaller and enclosed village hall. This was the first time such a collective and open protest occurred in the village. It represented the tipping point of the power balance among the farmers and the village government. From then on the farmer group received acknowledgement and respect from the village formal authorities. Hence, their night feast could be seen as a celebration of their success and victory, and also a marked appreciation for their collective action. The water from Batumoppo also represents a source for which the farmers' morale and energy have flowed. They realized they can do these things on their own.

It was dusk when I left Tompobulu. I saw the remains of the signpost with Arabic writings. Subhanallah. Alhamdulillah. Allahuakbar. They survived, just like the irrigation system.

Acknowledgments: Thanks to Penelitian Disertasi Doktor, Kemendikbudristek 2021 
Conflicts of interest: The authors declare no conflict of interest.

\section{References}

Euler, J. (2018). Conceptualizing the commons: Moving beyond the goods-based definition by introducing the social practices of commoning as vital determinant. Ecological Economics, 143, 10-16. https://doi.org/10.1016/j.ecolecon.2017.06.020

Ostrom, E (1990). Governing the Commons: The Evolution of Institutions for Collective Action. New York, USA: Cambridge University Press.

Prabowo, A., Batiran, K., Mansyur, M.A., (2011). Melawan Ketergantungan Kebijakan Pangan. Yogyakarta: InsistPress

Sirimorok, N., \& Hawi, S. (2014). Melacak Kerja Kolektif di Dua Desa Sulawesi Selatan. Makassar: Penerbit Ininnawa.

Vaccaro, I., \& Beltran, O. (2019). What Do We Mean by “the Commons?" An Examination of Conceptual Blurring Over Time. Human Ecology, 47(3), 331-340. https://doi.org/10.1007/s10745-019-00081-z 